\section{DIGITAL COMMONS \\ @ UNIVERSITY OF SOUTH FLORIDA}

\section{ABO: Interactive Journal for Women in the Arts, 1640-1830}

Volume 2

Issue 1 Volume 2.1 (Spring 2012): Open Access

Article 9

2012

\title{
Accessing Liberal Education
}

Alison Conway
University of Western Ontario, amconway@uwo.ca

Follow this and additional works at: https://digitalcommons.usf.edu/abo

Part of the Dramatic Literature, Criticism and Theory Commons, Educational Methods Commons, Feminist, Gender, and Sexuality Studies Commons, and the Literature in English, British Isles Commons

\section{Recommended Citation}

Conway, Alison (2012) "Accessing Liberal Education," ABO: Interactive Journal for Women in the Arts, 1640-1830: Vol.2: Iss.1, Article 9.

http://dx.doi.org/10.5038/2157-7129.2.1.8

Available at: https://digitalcommons.usf.edu/abo/vol2/iss1/9

This Pedagogy is brought to you for free and open access by Digital Commons @ University of South Florida. It has been accepted for inclusion in ABO: Interactive Journal for Women in the Arts, 1640-1830 by an authorized administrator of Digital Commons @ University of South Florida. For more information, please contact digitalcommons@usf.edu. 


\section{Accessing Liberal Education}

\section{Keywords}

ASECS, education, feminism, pedagogy

Creative Commons License

(c) (i) $\odot$

This work is licensed under a Creative Commons Attribution-No Derivative Works 3.0 License. 
This paper asks: how does teaching women's writing of the long eighteenth century provide us with an opportunity to reflect on the contribution we want to make to the larger program of a liberal arts education? In particular, I'm interested in how the answers we offer to this question might be different in 2011 than in 1991, when feminist theory and the "new" eighteenth century were at the center of critical conversations. What follows traces briefly the trajectory of my own career as a feminist critic over the two decades bridging this century and the last before turning to larger questions concerning our relation to the twenty-first century university. How can feeling somewhat old-fashioned help us broaden our awareness of what's at stake, both for feminism and literary studies, when we teach women's writing to our graduate and undergraduate students today?

I arrived on the Berkeley campus of the University of California in 1989, two years after the publication of Felicity Nussbaum and Laura Brown's essay collection, The New Eighteenth Century. Judith Butler's Gender Trouble appeared the following year. Catherine Gallagher, who would become my dissertation advisor, was working on Nobody's Story: The Vanishing Acts of Women Writers in the Market Place, 1670-1820. It seemed to me that after decades of struggle, the moment of critical truth had arrived for eighteenth-century studies. Never again would gender not appear a crucial topic to every reader; nor would women writers ever receive less than their fair share of critical attention. Living in the bliss of graduate student egomania, it never occurred to me that critical interests come and go, and that my moment, too, would pass.

Twenty years later, I felt strangely self-conscious when I proposed a summer graduate course on British women authors before 1800 for our M.A. students. The course sounded weirdly oldfashioned to my ears, and I fretted that somehow I was doing a disservice to graduate students by not teaching them material that reflected current trends in literary studies, especially when I contemplated teaching a survey of feminist theory alongside the works dating back to Simone de Beauvoir. 'Does anyone read Elaine Showalter anymore?' I wondered.

I experienced a similar self-consciousness while completing a book on courtesan narrative, published in 2010. Let this book find a publisher, I prayed, and I will never write about gender and sexuality again. It seems I am not alone in this feeling. Comparing the 2011 ASECS conference program to that of the Austin meeting of 1996, I calculate roughly that session titles naming women and women authors have dropped by almost $50 \%$, from about $15 \%$ to $8 \%$ of the program. While this drop may indicate that questions of gender and sexuality and the subject of eighteenth-century women's writing have been integrated into current research programs, it seems clear the field has moved on. Of course, this trend reflects the realities governing all scholarship: an interest in new critical methodologies, a shift of attention to new objects of inquiry, a new layer of knowledge that builds upon or incorporates or refutes earlier findings.

For feminists, however, the evolution of critical conversations carries with it a variety of consequences. Most immediately, it puts at risk our ability to teach women writers. As Toni Bowers noted in her 2009 Eighteenth Century: Theory \& Interpretation (ECTI) essay, no editions of Behn's Love-letters between a Nobleman and his Sister or Manley's The New Atalantis are currently available, despite the fact that Ros Ballaster and Janet Todd produced excellent editions of these works for Penguin in the 1990s (57). In the same ECTI issue, Joan DeJean observes the dearth of scholarly editions of French women's texts. Without editions to 
teach, we will lose not only primary texts but also a body of scholarship made available by editors in the latter part of the twentieth century.

We can no longer assume a critical privilege for women's writing on the basis that its study represents "cutting edge" research. We will have to find a new language, one that may be more explicitly political, and one that may also be less so. That is, on the one hand, we need to continue to advocate for its commitment to a larger program of social justice in the university and highlight the disjunction between the idea that literary studies have "moved on" from women's writing and feminist theory and the realities shaping women's everyday lives. On the other hand, we need to identify ourselves with a larger community of colleagues, one that is not necessarily committed to our specific political agenda, but that is also working to combat the corporatization of the university. Here we may have to confront our discipline's conflicted relation to the language of liberal self-cultivation. As Lisa Ruddick notes of our poststructuralist tendency to avoid this conversation: "[I]n behaving thus, we are of course suppressing the very thing that makes us attractive to many of our majors and that helps validate us in the eyes of the outside world" (31). Feminists in the academy need to articulate what contribution they want to make as part of a larger collective effort to re-engage students in the idea of liberal education, and in doing so grapple with our habitual hermeneutics of suspicion.

We have all encountered students who seem to have no idea why they are at university. In a recent New Yorker article, Louis Menand reflects on the rising number of students who appear disengaged from their education: "[W] system without believing that what goes on in it really matters, it's hard to transform minds" (79). Pressured by high school counsellors and parents who view a university degree as a ticket to employment in a competitive job market, alienated students question the relevance of works we assign and of the writing we require from them. Our first job, then, is to invite them into a conversation that starts with the university and works inward to the space of the classroom and an imaginative engagement with Restoration and eighteenth-century literature and culture. This process is one of progressive de-familiarization, one that seeks, first, to shift the student's obsession with completing her degree and getting on with her life in favour of an alternative vision, one that renders the time spent at university meaningful in and of itself. In the early weeks of the semester, for ten minutes at the beginning or end of classes, I engage students in a wide-ranging Q\&A regarding the value of an arts education, a subject most report never to have considered. Second, I try to create a classroom environment that allows students to separate themselves from the exigencies of their daily lives, most immediately the electronic devices that hold them hostage for hours a day: "[T]eaching students techniques of awareness, concentration, and means of disciplining their attention is absolutely essential in our era of fragmentation, everincreasing speed, multitasking, and continuously interrupted attention,” note Parker J. Palmer and Arthur Zajonc. (179). I ban laptops and ask students to read aloud to keep their attention focused on the texts at hand. Short response papers allow students to try out ideas before taking on the challenges of a formal essay.

Of course I am partial, but I believe our field lends itself particularly well to challenging students' tendency to universalize ideas and values that are historically and culturally specific. Teaching women writers allows me to show the variations of practices and discourses within any given moment, and how critique works-as, for instance, when Mary Astell counters Locke's 
empiricism. Aphra Behn's accounts of libertinism and slavery allow students to see that while works may raise important questions, they do not always provide answers, and that there is value in the interrogative mode. Our conversations about the shifts in understandings of gender and sexuality over the course of the long eighteenth century allow students to recognize the permeability of cultural norms and personal identities. Within this context, "feminism" takes on a new and larger meaning for students (who often refuse the term out of hand at the beginning of the class) while casting the idea of "relevance," also, in a new light.

Recently I taught a fourth-year Honours seminar titled "Women, Money, and the Novel: Readings in Frances Burney and Jane Austen.” The course pursued three lines of investigation. First, it studied Burney's and Austen's careers as professional authors, tracing the series of negotiations and contracts that secured their earnings as writers. We compared cost of living rates and the gendered expectations regarding money that shaped the writing lives of these two women. Second, the course examined a range of historical topics, including shopping, bank notes, gambling, and other money-related practices. Third, we undertook a close reading of selected novels of Burney and Austen, studying how their representations engaged with the financial realities with which both authors were intimately acquainted and the larger historical context of late eighteenth- and early nineteenth-century Britain. Additionally, we took fifteen minutes at the end of a three-hour seminar to discuss women's engagement in financial issues today, reading selected journalism and essays. These conversations brought our literary analysis alive as a subject of the most immediate importance for my students. Very few students (all women, all graduating seniors), for instance, could identify the approximate salary range of their chosen career at the beginning of the course.

This subject would seem to risk validating the idea of the university as vocational: "Look, students learn the value of a dollar (or a pound) by reading Frances Burney!” But, in fact, the goal of the course was to move in a different direction, to shift money from "fact" to a site of emotional and social consequence, part of a larger communal nexus of obligation and care as well as individual independence. The course also provided an opportunity for the students to see their professor as both an intellectual and a woman: I would often lead off end-of-class conversations describing some recent moment of financial confusion or clarity in my life. The ability to engage students in this way animates my work on women writers and feminist theory as a pedagogical principle, demonstrating to me, as well as to my students, how our work in the classroom takes us back into the world with a heightened awareness of the cultural politics taking shape around us: and how we might, in turn, shape them.

Years scrambling for a job and tenure can harden the best of us into ruthless individualists cut off from ourselves and our students. Patricia Owen-Smith writes: "I have come to understand that the academic world of higher education has been structured in such a way so as to normalize and promote alienation” (157). This problem has been heightened by the ongoing corporatization of the university. Administrators look for research performance indicators and winning strategies for grant retrieval. Feminist contributions to the university's sense of its mission and its commitment to a pedagogy of social justice is neither here nor there within this model. As a young scholar, it seemed urgent that I prove that my teaching was actively demonstrating my research advances; I did what the university asked of me. While I continue to enjoy introducing students to any recent discoveries I've made in my work, I ask first, now, when contemplating a 
new course proposal: How can I use what I've learned as a feminist critic in the field of eighteenth-century studies to engage my students in a larger educational metamorphosis?

The challenge, for feminists committed to continuing research on gender and sexuality and women writers, is to continue to insist on the link between these concerns and larger communal values, including pedagogy. (Louis Menand's article notes, depressingly, the research that shows compensation negatively correlating to pedagogical commitment (77)). The fact that we are no longer on the cutting edge-in eighteenth-century studies, in any case-provides us with an opportunity to reflect on why we do what we do, to take a moment to pause. Palmer and Zajonc observe that in recent years "the academy has largely lost one of its most critical preconditions: the quietude that allows for real reflection on what we have seen and heard, felt, and thought, a quietude that has been overwhelmed by overactivity and frenzy" (145). My sense of critical belatedness, I find, helps me to approach eighteenth-century women's writing as a lifelong engagement with a field through which I move, forward and backward, looking for answers to questions both political and existential.

To pause offers us, also, a chance to reconnect with our colleagues, both near and far. The communities of women writers we write about were forged out of friendship and necessity, and ours can be, also. How often do we take time to read each other's work in draft form? At home, connections need to be established across disciplines for local institutional cultures to change. In sum, we need to build on the principle of collective action that is fundamental to feminism to foster what Palmer and Zajonc call "transformative conversation" (136) about our future in the academy. Only then will we establish a compass point for the university that is not set to Corporate North and access for ourselves and for our students a reason for being there. 
Works Cited

Bowers, Toni. "The Achievement of Scholarly Authority for Women: Trends in the Interpretation of Eighteenth-Century Fiction.” Eighteenth Century: Theory and Interpretation 50.1 (2009): 51-71. Academic OneFile. Web. 13 Aug. 2011. http://dx.doi.org/10.1353/ecy.0.0025

Menand, Louis. "Live and Learn: Why We Have College." The New Yorker, 87.16 (6 June 2011): 74-80. Print.

Owen-Smith, Patricia. "Knitting Through the Hallelujah,” Appendix A, Palmer and Zajonc 157-161. Print.

Palmer, Parker J., and Arthur Zajonc, with Megan Scribner. The Heart of Higher Education: A Call to Renewal. San Francisco: Jossey-Bass, 2010. Print.

Ruddick, Lisa. “The Unnamed Work of English.” ADE Bulletin 151 (2011): 29-35. Web. 13 Aug. 2011.

Notes

For more from this author, please see this syllabus on Austen and Burney and this syllabus on women and the Enlightenment.

Other essays in this series:

Introduction

Gender and Genre

Dangerous Delusions

Place and Contemplative Pedagogy 